\title{
Outorgado título de professor honorário "post-mortem" a José Xavier Carvalho de Mendonça.
}

Em solenidade realizada na sala João Mendes desta Faculdade, em 14 de novembro, por ocasião do encerramento dos cursos juridicos de 1961, foi outorgado pela Congregação dos Professôres o título de professor honorário "post-mortem" a José Xavier Carvalho de MendonçA, comemorando-se o centenário de seu nascimento.

Presidida a solenidade pelo Diretor da Faculdade, Prof. Luís Antônio da Gama e Silva e presente a Congregação, foi dada a palavra ao professor emérito Dr. WALdemar Martins Ferreira que exaltou a figura de jurista do homenageado em oração transcrita na abertura dêste volume.

Agradecendo a homenagem em nome da família. o Dr. Roberto Carvalho de Mendonça proferiu o seguinte discurso:

\section{Discurso do Dr. Roberto Carvalho de Mendonça.}

“Ao pisar pela primeira vez neste recinto para em nome da família de CarvalHo DE MENDonça agradecer a elevada honraria "post-mortem" deferida a seu Chefe, confesso-me lealmente tomado dos mais sérios temores, pois transmitir em grau verdadeiro o quanto nos calou esta homenagem parece-me tarefa demasiado forte para minhas fôrças. 
Tôda imagem que nos aflora ao pensamento para traduzir a imensa gratidão de que nos vemos possuídos, ao dirigirmos a palavra a êste cenáculo de altos cultores do saber jurídico, se nos afigura insatisfatória, como expressão exterior de nossos sentimentos.

Sinto agora e mais uma vez como estava certo ao afirmar perante o Instituto dos Advogados Brasileiros, quando da tocante festa ali realizada por ocasião do centenário de nascimento de nosso Chefe, que São Paulo, terra acolhedora onde viveu CARvalHo de Mendonça a maior parte de seus dias, foi o lugar a que êle dedicou o melhor quinhão de suas afeições, e onde tanto souberam amá-lo.

A homenagem prestada pelos Doutos Mestres desta Alta Congregação é ainda reflexo dêste elevado amor ao velho jurista.

Já confessara, aliás, Carvalho de Mendonça, em discurso de agradecimento proferido a 9 de setembro de 1925, ao receber o título de sócio honorário do Instituto dos Advogados de São Paulo:

“À fecunda e generosa terra de São Paulo devo o pouco que sou; aqui formei a minha instrução jurídica e eduquei o caráter".

Cultuando-lhe a memória, como incansável estudioso do Direito, os grandes mestres desta Faculdade estão dando uma lição de elevado incentivo aos jovens, porque lhes testemunham a confortante messe de respeito e veneração que uma dura existência de estudos e pesquisas pode conquistar.

Reflete-se neste exemplo uma das rutilantes facetas da gloriosa missão dos professôres desta famosa faculdade "que tem verdejado desde 1827 até hoje, sem que haja deixado de florir, todos os anos, em homens eminentes que glorificam a terra que lhes deu o berço", na expressão feliz e verdadeira de Spencer Vampré ${ }^{1}$.

1. Memórias para a História da Academia de São Paulo, vol. 1, p. 2. 
A missão cada vez mais necessária, espinhosa e difícil dos mestres de direito no agitado cenário que hoje se desenrola diante da humanidade angustiada e perplexa, tem encontrado nesta Faculdade pregadores de escol, semeando ensinamentos que irão certamente estruturar a sociedade de amanhã.

"Nesta fase histórica da vida do Direito, quando múltiplos e graves fatôres operam no sentido de sustar o curso normal de seu desenvolvimento e procuram destruir, de ponta a ponta, tôda a ordem jurídica que caracteriza a sociedade contemporânea", segundo VICENTE RÁo, outro dos eminentes Mestres desta Faculdade ${ }^{2}$; neste momento em que, na original imagem de Camus ${ }^{3}$, "a função da humanidade esclarecida já não se destina a refazer o mundo-mas a evitar que o mundo se destrua"; e, diante desta geração de evidente transição, quando os homens de cultura e sensibilidade estão percebendo que a direção social deve pertencer a uma classe espiritual imbuída de altas e verdadeiras preocupações sociais (finalidade mesma do Direito); os vossos sábios ensinamentos são ávidamente aguardados e frutificarão para a posteridade, como frutificaram os de vossos antecessores, estruturando em grande parte a nossa nacionalidade.

Vossa palavra representa a voz dos juristas puros, daqueles que, no admirável conceito de Vicente Ráo ${ }^{4}$, "não visam aplausos demagógicos de que não precisam. Ao contrário, afirmam corajosamente os verdadeiros princípios científicos do Direito, proclamando-os alto e bom som, fazendo-os vingar e sobreviver dentro do tumulto legislativo das fases de transformação ditadas pelas contingências sociais, dêles extraindo as regras disciplinadoras das novas necessidades, sem sacrifício da liberdade, da dignidade e a personalidade do ser humano".

2. O Direito e a Vida dos Direitos, vol. 1, p. 7.

3. Apud. Prado Kelly, discurso proferido no Instituto dos Advogados Brasileiros, por ocasião da entrega do Prêmio Teixeira de Freitas ao Prof. Haroldo Valladão.

4. Op. cit., p. 13. 
Assim, diante destas paredes onde se abrigam e se refletem as saudades pelos sábios juristas que delas já se afastaram e onde pousam nossos olhos em respeitoso preito de esperança e admiração pelos que aqui continuam, apresento a esta Alta Congregação nossos mais profundos e imorredouros agradecimentos".

Entrega do título ao Dr. Roberto Carvalho de Mendonça.

Após as palavras do Dr. Roberto Carvalho de MenDoNĢA, designou o Diretor ao professor emérito Dr. WaLdemar Martins Ferreira como o "maior comercialista vivo" para fazer a entrega do título ao Dr. Roberto Carvalho de Mendonça, filho do homenageado.

Foram dados a público os termos em que era redigido o título e que são os seguintes:

"Faculdade de Direito da Universidade de São Paulo.

O doutor Luís Antônio da Gama e Silva, Diretor e Professor Catedrático, faz público que, pela ocorrência, em 24 de setembro de 1961, do centenário do nascimento do Dr. José Carvalho de Mendonça, a Congregação de seus professôres deliberou outorgar-lhe, post-mortem, o título de professor Honorário, em reconhecimento de seus grandes méritos como consolidador do Direito Comercial Brasileiro e mandar inscrever o seu nome no quadro de seus professôres daquela categoria, para que perdure na admiração das gerações vindouras". 